\title{
ERKINIO ENCEFALITO KINTANČIO SERGAMUMO ITAKA KLINIKINEI FORMAI
}

\author{
Gabrielè Kalvelytė ${ }^{1}$, Austẻja Žibūdaitė ${ }^{1}$, Daiva Radzišauskien $\dot{e}^{2}$ \\ ${ }^{1}$ Vilniaus universiteto Medicinos fakultetas, \\ ${ }^{2}$ Vilniaus universiteto Santaros kliniku Infekciniu ligu centras
}

Raktažodžiai: epidemiologija, erkinis encefalitas, meningoencefalomielitas, vakcinacija

\section{Santrauka}

Darbo tikslas. İvertinti sirgusiujų erkiniu encefalitu (EE) 2011-2014 m. ir 2005-2008 m.epidemiologiją ir klinikini pasireiškimą.

Darbo objektas. Atliktas retrospektyvinis erkinio encefalito tyrimas Vilniaus rajone 2011-2014 m., kai sergamumas buvo didelis (13,1 atvejai 100000 gyventoju) ir 2005-2008 m., kai sergamumas buvo mažas (3,7 atvejai 100000 gyventoju). Ištirti Vilniaus rajono suaugę pacientai, sirgę erkiniu encefalitu ir gydyti Vilniaus universiteto Santaros klinikų Infekcinių ligų ir Neurologijos centruose 2005-2014 m.

Metodas. I tyrimą buvo ịtraukti tik laboratoriškai patvirtinti atvejai: nustačius EEV IgM ir IgG kraujyje arba EEV IgM likvore. Pacientai buvo suskirstyti i dvi grupes pagal sergamumo lygio laikotarpius, tai 2011-2014 m. $(n=417)$ ir 2005-2008 m. $(n=130)$. Grupès lyginamos pagal epidemiologiją, kliniką ir liekamuosius reiškinius. Statistinè analizè atlikta naudojant R statistinị paketą, chi-kvadrato, Fišerio (Fisher) testus; $\alpha=0,05$.

Rezultatai. 2011-2014 m., kai sergamumas Vilniaus rajone didejjo, palyginus su 2005-2008 m. nustatyta, kad sumažèjo meningitinių ligos formų - 33/417 $(7,91 \%)$ palyginus su $19 / 130(14,62 \%),(p=0,023)$, taip pat sumažejo ir encefalitinių formų - 12/417 $(2,88 \%)$ lyginant su $9 / 130(6,92 \%)(\mathrm{p}=0,023)$. Meningoencefalomielitinių ligos formų padaugejo - 18/417 $(4,32 \%)$ palyginus su $1 / 130(1,32 \%)(p=0,054)$. Meninginių simptomų pasireiškimo dažnis sumažejo - 255/417 (61\%) lyginant su 100/130 (76,92\%) $(\mathrm{p}=0,001)$. Padidejo šių simptomų/sindromų pasireiškimo dažnis: ataksijos 146/416 $(35,1 \%)$ palyginus su 32/130 $(24,63 \%)(p=0,026)$, tremoro $229 / 417$
$(54,78 \%)$ palyginus su 49/130 $(37,69 \%)(\mathrm{p}=0,001)$, galvinių nervų pažeidimo 188/417 (44,98\%) palyginus su $44 / 130(33,85 \%)(\mathrm{p}=0,025)$ ir galvos skausmo $385 / 416(92,55 \%)$ palyginus su $112 / 130(86,15 \%)$ $(\mathrm{p}=0,026)$. Padažnèjo liekamieji reiškiniai: galvos svaigimas $(\mathrm{p}=0,028)$, ataksijos $(\mathrm{p}<0,05)$ bei tremoras $(\mathrm{p}<0,01) .2011-2014$ metais buvo 4 mirtys $(0,96 \%)$ palyginus su 2005-2008 metais, kai nebuvo nei vienos mirties $(\mathrm{p}=0,264)$.

Išvados. Vilniaus rajone nustatytas tiesioginis didèjančio erkinio encefalitu sergamumo ir kintančių ligos formų ryšys. Didejjant erkinio encefalito sergamumui Vilniaus rajone daugeja meningoencefalitinių, mažejja meningitinių ir encefalitinių ligos formų, dažnesni liekamieji reiškiniai, dideja mirštamumas.

\section{Ivadas}

Erkinis encefalitas (EE) - paskutiniais dešimtmečiais didejanti sveikatos problema Europoje [1]. Tai virusinè centrinès nervų sistemos (CNS) infekcija. Erkinio encefalito virusas yra vienas iš flavivirusų šeimos narių, kurị perneša iksodinès erkès. Šis virusas pagal molekulinę filogenezę skirstomas ị tris potipius: Tolimųjų rytų, Sibiro, Europos, būtent pastarasis potipis yra vienintelis iki šiol aptiktas Lietuvoje [2].

Erkiniui encefalitui būdinga dvibangè eiga. Pirmosios fazès metu, kuri trunka apie vieną savaitę, virusas patenka ị kraują ir jame dauginasi, kliniškai pasireiškia karščiavimu, gripo simptomais, sąnarių skausmu ir kaulų „laužymu”. Toliau besitęsiančio besimptomio periodo metu virusas iš kraujo keliauja i „,tarpinius” organus, čia toliau dauginasi. Šiuo laikotarpiu simptomai nebūdingi [3]. Vèliau prasideda antroji fazè, kuomet virusas praeina hematoencefalinį barjerą ir liga pasireiškia meningitu, meningoencefalitu ar meningoencefalomielitu [4]. Iki šiol nèra EE specifinio gydymo, ši liga gydoma tik simptomiškai [5]. Ilgalaikiai simptomai nustatyti $31-36 \%$ segančių, mirtingumas $2 \%$ visų atvejų 
Lietuvoje [6]. Lietuvoje virusą platina Ixodes ricinus rūšies erkès [7]. Erkių didžiausias aktyvumas stebimas nuo kovo pabaigos iki lapkričio vidurio, tam daro įtaką tinkama aplinkos temperatūra $+5-+7$ laipsniai [6]. Erkinio encefalito klinika gali būti lengva, kuomet pasireiškia meningitinè forma, vidutinè ir sunki forma siejama su meningoencefalitu ir meningoencefalomielitu. Simptomai taip pat yra klasifikuojami ị lengvus, vidutinius ir sunkius pagal tai, kokią įtaką jie daro paciento gyvenimo kokybei [8].

Darbo tikslas - palyginti epidemiologini ir klinikini pasireiškimą sirgusių erkiniu encefalitu 2011-2014 m. ir 2005-2008 m.

\section{Darbo objektas ir metodas}

Atliktas retrospektyvinis tyrimas: sergamumas erkiniu

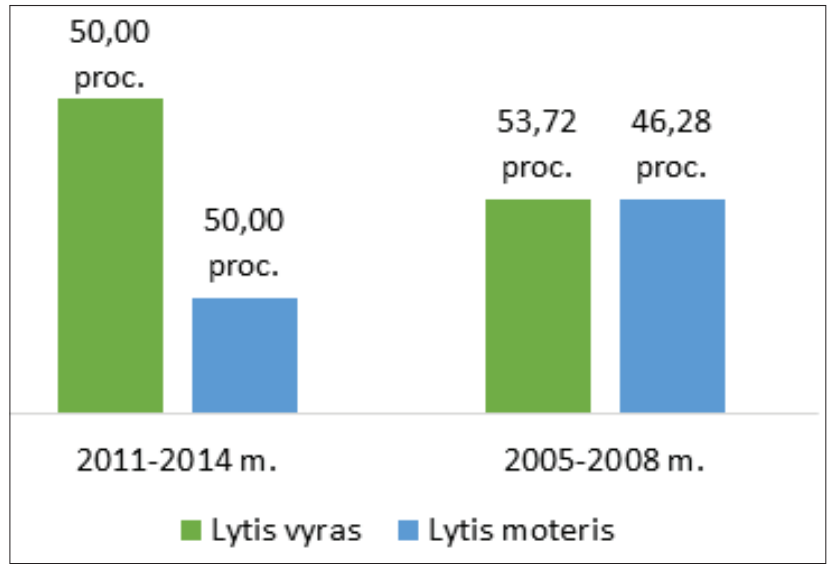

1 pav. Demografiniai sergančiujų erkiniu encefalitu 2005-2008 m. bei 2011-2014 m. $(n=548)$ duomenys.

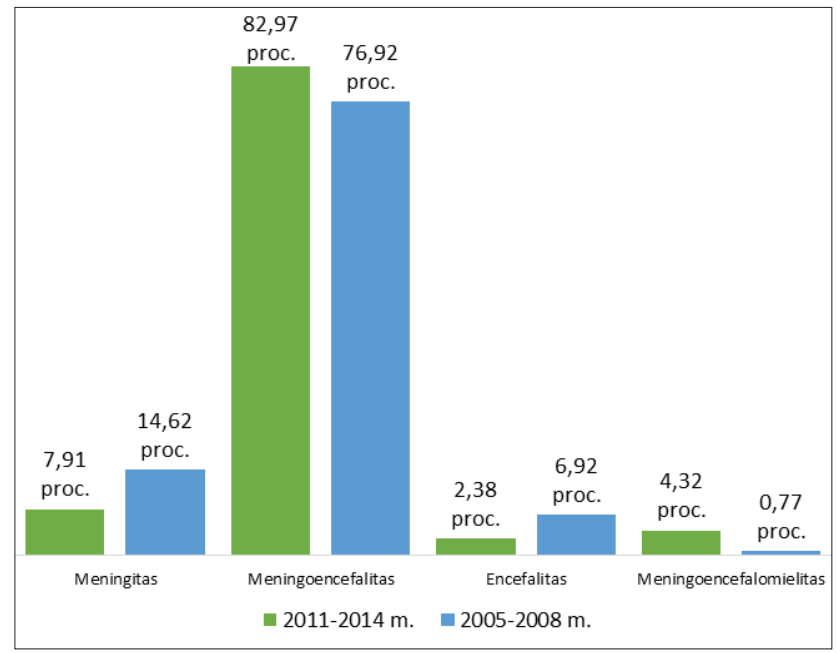

2 pav. Sergančiųjų erkiniu encefalitu 2011-2014 m. bei 2005-2008 m. $(n=548)$ ligos formos. encefalitu Vilniaus rajone 2011-2014 m., kai jis buvo didelis (13,1 atvejai 100000 gyventojų) ir 2005-2008 m., kai jis buvo mažas (3,7 atvejai 100000 gyventojų). Ištirti Vilniaus rajono suaugę pacientai, sirgę erkiniu encefalitu ir gydyti Vilniaus universiteto Santaros klinikų Infekcinių ligų ir Neurologijos centruose 2005-2014 m. I tyrimą buvo įtraukti tik laboratoriškai patvirtinti atvejai: imunofermentinès analizès metodu (ELISA) nustačius EEV IgM ir IgG kraujyje arba EEV IgM likvore. Pacientai buvo

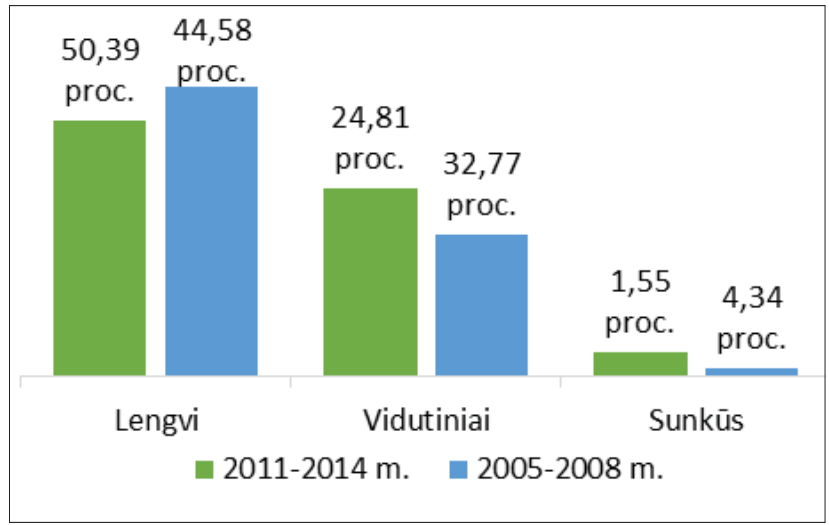

3 pav. Sirgusiujų erkiniu 2011-2014 m. bei 2005-2008 m (n=548) liekamieji reiškiniai.

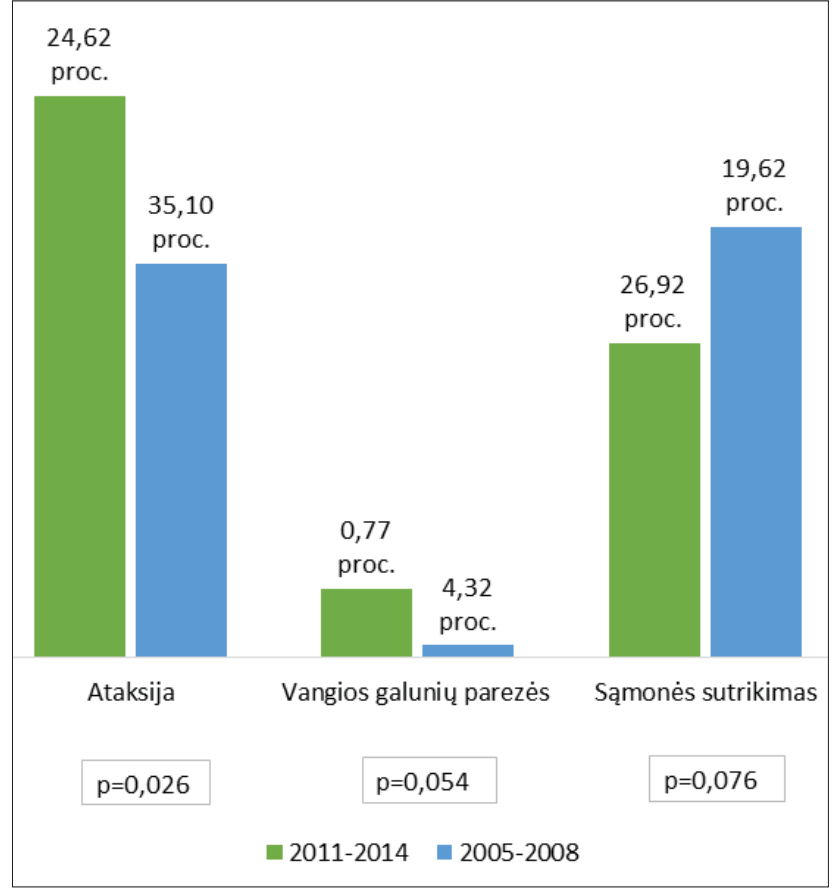

4 pav. Sirgusiųjų erkiniu encefalitu 2005-2008 metais bei 20112014 m. (n=548) klinikiniai veiksniai, kurie turejjo ịtakos atsirasti liekamiesiems reiškiniams. 
suskirstyti i dvi grupes pagal sergamumo lygio laikotarpius, tai 2011-2014 m. $(\mathrm{n}=417)$ ir 2005-2008 m. $(\mathrm{n}=130)$. Grupès lyginamos pagal epidemiologiją, kliniką ir liekamuosius reiškinius. Statistinè analizè atlikta naudojant $\mathrm{R}$ statistini paketą, chi kvadrato, Fišerio testus; $\alpha=0,05$.

Atsižvelgiant ị kliniką, erkinio encefalito atvejai buvo suskirstyti ị meningitinius, meningoencefalitinius ir meningoencefalomielitinius. Meningitinei erkinio encefalito formai būdinga: galvos skausmas, pykinimas, vèmimas, sprando raumenų rigidiškumas. Pačiai dažniausiai formai - meningoencefalitinei - būdingi ne tik meningitiniai, bet ir encefalito požymiai - sąmonès, pusiausvyros ir koordinacijos sutrikimai, tremoras, ataksija. Meningoencefalomielitinès formos metu šalia išvardintų simptomų pasireiškia nugaros smegenų ir šaknelių bei nugarinių nervų pažeidimo simptomai - periferinès ar spazminès parezès, laidinio ir segmentinio tipo jutimo sutrikimai, vegetacinių funkcijų sutrikimai [11].

Erkinis encefalitas pagal kliniką taip pat skirstomas ị lengvą, vidutinị ir sunkų. Lengva forma siejama su meningitu, vidutinè ir sunki su meningoencefalitu ir meningoencefalomielitu. Sunkia forma laikoma, kuomet nustatomi difuziniai smegenų pažeidimai, daugiažidininė CNS simptomatika, sunki ataksija, kuomet pacientas negali vaikščioti. Visi pacientai su infekciniu mielitu taip pat priskiriami sunkiai ligos formai. Vidutinio sunkumo liga nustatoma su mažesniais smegenų pažeidimais ir CNS simptomatika. Lengvo sunkumo liga laikoma tik su meningito simptomatika arba trumpalaikiais encefalito simptomais (tremoras, ataksija).

Visi simptomai dar yra klasifikuojami pagal tai, kokią itaką daro paciento, persirgusio erkiniu encefalitu, gyvenimo kokybei. Lengvi simptomai nedaro jokio reikšmingo poveikio, vidutiniai - sukelia nepatogumų kasdieniniame gyvenime, o sunkiems simptomams priskiriami tokie, kurie trukdo tęsti ankstesnes kasdienines veiklas [13]. (Gautas Bioetikos sutikimas, 2014 m. Nr. 158200-14-742-259).

\section{Rezultatai}

Epidemiologija ir demografija ( $\mathrm{n}=548) .2011-2014 \mathrm{~m}$. ir 2005-2008 m. pacientų, sirgusių EE, buvo 548. Iš šių tiriamujų 418 atvejų 2011-2014 m. (374 atvejai Infekcinių ligų centre ir 44 atvejai Neurologijos ligų centre) ir 130 buvo diagnozuota 2005-2008 m. (iš jų 94 buvo hospitalizuoti Infekcinių ligų centre ir 36 Centrinès nervų sistemos ligų centre). Labai maža dalis pacientų pradèję skiepų kursą susirgo EE: 2011-2014 metais 9/394 (2,28\%), 2005-2008 m. $-5 / 99(5,05 \%)$, tačiau nei vienas iš susirgusiujų nebuvo praejęs viso skiepijimo kurso. Demografinis pasiskirtymas grupèse pateiktas 1 paveiksle. Pirmoje grupeje vyrų sirgo $224 / 417$ (53,72\%), antroje $-65 / 130(50 \%), p=0,46$, o moteru pirmoje grupèje $193 / 417$ (46,28\%), antroje grupèje $65 / 130$
$(50 \%), \mathrm{p}=0,46$.

Ligos formos $(\mathrm{n}=548)$. Pirmoje grupeje meningitinių ligos formų užfiksuota $33 / 417$ (7,91\%), antroje - 19/130 $(14,62 \%), p=0,023.2011-2014 \mathrm{~m}$. meningoencefalomielitinių formų buvo 18/417 (4,3\%), 2005-2008 m. - 1/130 $(0,77 \%), p=0,054$. Encefalitinès formos pirmoje grupeje $12 / 417$ (2,88\%), antroje $-9 / 130(6,92 \%), p=0,023$ ( 2 pav.).

Ligos simptomai $(\mathrm{n}=548)$. Klinikiniai simptomai buvo suskirstyti i tuos, kurie pasireiške iki hospitalizacijos ir jos metu. Dažniausias simptomas iki hospitalizacijos - karščiavimas, pirmoje grupejje 240/418 (57,42\%), antroje grupeje - 89/129 (61,24\%), $p=0,441.2011-2014$ m. sirgusiems erkiniu encefalitu Parkinsono sindromas nebuvo užfiksuotas, o ankstesniu laikotarpiu šis sindromas pasireiškè dviem pacientams, $(p=0,011)$, taip pat dažniau buvo skundžiamasi ìvairių sričių tremoru: pirmoje grupeje 29/418 (6,94\%), antroje $-17 / 130(13,08 \%), p=0,03.2011-2014 \mathrm{~m}$. galvos skausmu skundèsi 385/416 (92,55\%), 2005-2008 m. $112 / 130(86,2 \%), p=0,026$. Pirmoje grupeje ataksija pasireiškè 146/416 (35,1\%), antroje - 32/130 $(24,6 \%), \mathrm{p}=0,026$. 2011-2014 m. galūnių parezių buvo 15/418 (3,59\%), 2005 2008 m. $-10 / 130$ (7,69\%), p=0,05. Diplopija buvo pirmoje grupeje $18 / 418(4,31 \%)$, antroje $-1 / 130(0,77 \%), p=0,05$.

Pagrindiniai simptomai hospitalizacijos metu buvo tokie patys abejose grupėse: galvos skausmas pirmoje grupejje $404 / 418(96,65 \%)$, antroje $-124 / 130(95,38 \%), p=0,501$, taip pat galvos svaigimas pirmoje grupeje $314 / 417(75,3 \%)$, antroje $-91 / 130(70 \%), p=0,229$, mialgijos pirmoje grupeje $33 / 417(7,91 \%)$, antroje $-16 / 128(12,5 \%), p=0,113$, vèmimas pirmoje grupeje $48 / 414(11,59 \%)$, antroje - 23/130 $(17,69 \%), p=0,072$.

Neurologiniai simptomai $(\mathrm{n}=548)$. Lyginant sirgusiuosius, meninginiai simptomai retèjo: pirmoje grupejje 255/418 (61\%), antroje $-100 / 130$ (76,92\%), $\mathrm{p}=0,001$. Atitinkamai pateikiami ir kiti neurologiniai simptomai: sprando rigidiškumas 238/417 (57,07\%) ir 93/130 (71,54\%), $\mathrm{p}=0,003$, Kernigo simptomas $158 / 417(37,89 \%)$ ir $79 / 130(60,77 \%)$, $\mathrm{p}<0,05$, somnolencija $71 / 418(16,99 \%)$ ir $32 / 129(24,81 \%)$, $p=0,047$. Dezorentacija pirmoje grupeje $46 / 418(11 \%)$, antroje $-25 / 130(19,23 \%), p=0,015$. Dizfazija pirmoje grupeje $6 / 418(1,44 \%)$, antroje $-6 / 130(4,62 \%), p=0,03$. Tremoras pirmoje grupeje 229/418 (54,78\%), antroje $49 / 130(37,69 \%), p=0,001$. Spazminès galūnių parezès pirmoje grupeje $7 / 418(1,67 \%)$, antroje $-7 / 130(5,38 \%)$, $\mathrm{p}=0,019$. Galvinių nervų pažeidimai pirmoje grupèje 188/418 $(44,98 \%)$,antroje $-44 / 130(33,85 \%), p=0,025$. Patologiniai refleksai pirmoje grupeje $37 / 417$ (8,87\%), antroje $-22 / 130$ $(16,92 \%), p=0,01$.

Laboratoriniai tyrimai antros karščiavimo bangos metu $(\mathrm{n}=548)$. Pirmoje grupejje ENG (>30) buvo 33/418 (8,71\%), 
antroje $-40 / 130(35,09 \%), p<0,05$. Pirmoje grupeje CRB $(>30)$ buvo $5 / 418(1,21 \%)$, pacientu, antroje $-12 / 130$ $(40,43 \%), \mathrm{p}<0,05$. Pirmoje grupeje leukocitozè $(>9) 71 / 418$ $(17,11 \%)$, antroje $-71 / 130(54,62 \%), p<0,05$.

Liekamieji reiškiniai $(\mathrm{n}=548) .2011-2014 \mathrm{~m}$. nustatytos keturios mirtys (3 pav.) - 4/416 (0,96\%), 2005-2008 m. neužfiksuota nei vienos, $\mathrm{p}=0,264$. Galvos svaigimas pirmoje grupeje 169/372 (45,43\%), antroje $-37 / 110(33,64 \%), p=$ 0,028 . Ataksija pirmoje grupeje $222 / 372(59,68 \%)$, antroje $43 / 110(39,09 \%), p<0,05$. Tremoras pirmoje grupeje $127 / 372$ $(34,14 \%)$, antroje $-19 / 110(17,27 \%), p<0,05$. Liekamuju reiškinių atsiradimo rizika yra vyresnis amžius, sąmonès sutrikimas, ataksija, parezès (4 pav.).

\section{Diskusija}

Erkinis encefalitas (EE) - dažniausia Europoje centrinès nervų sistemos (CNS) infekcija [9]. Lietuva yra viena iš endeminių erkinio encefalito šalių [10]. Tam turèjo įtakos didelis miškingumas (30\%), daug žemès sklypų nėra naudojami ir apsodinti, taip pat palankios klimato sąlygos erkių dauginimuisi [11].

Lietuvoje erkinio encefalito infekcijos vis dažniau buvo pradètos fiksuoti $1994 \mathrm{~m}$., tam galèjo turèti įtakos erkių gausèjimas, pasikeitęs klimatas, socialiniai veiksniai, geresnè laboratorinè diagnostika.

Vienintelis efektyvus būdas išvengti ligos yra vakcinacija [12]. Lietuva, nors ir priklauso didelès rizikos grupėms, tačiau skiepijimo apimtis yra labai maža. Austrijoje 1971 m. buvo sukurta pirmoji inaktyvuota erkinio encefalito vakcina. Būtent ten pradejus aktyviai skiepyti gyventojus sergamumas sumažejo kelis kartus. Vakcinuoti galima ịprastine arba pagreitinta tvarka. İprastine vakcinacija laikoma, kuomet pirmosios dvi vakcinos suleidžiamos kas 1-3 mén., trečioji praejjus 9-12 mèn. po antrosios, o stiprinančios dozès leidžiamos kas 3-5 metus. Pagreitinta tvarka skiepijuoma, kuomet yra prasidejjęs erkių aktyvumo sezonas, dažniausiai taikoma schema: 0,7,21 dienomis ir sustiprinamoji dozė po 12-18 mèn.

Apskaičiavome, kad daugiausia pacientų abiejose grupèse sirgo meningoencefalitu. Meningitine forma pacientai sirgo rečiau, tai gali būti dèl to, kad meningitas yra sunkiau diagnozuojamas, ypač jei pacientus kamuoja tik bendras negalavimas. Šios ligos formos dar labiau sumažèjo 2011-2014 $\mathrm{m}$., tačiau reikšmingai padaugèjo meningoencefalomielitinių bei encefalitinių formų. Šių sunkių formų dažnèjimo priežastis galètų būti ne tik geresnè diagnostika, tačiau ir kitų viruso potipiu paplitimas Lietuvoje. Lietuvos kaimyneje Latvijoje atrasti visi trys erkinio encefalito viruso potipiai, dèl to reikètų atlikti tyrimus dèl viruso potipių paplitimo ir mūsų šalyje.
Nors per pastaruosius metus žinios apie klinikinę būklę pagerèjo, vis dar pasitaiko nediagnozuotų arba per vèlai diagnozuotų atvejų. Taigi ir toliau reikia tobulinti žinias apie patogenezę ir gydymą. Remiantis epidemiologiniais duomenimis dažniausias viruso rezervuaras yra smulkieji graužikai, būtent jie yra pagrindiniai iksodinių erkių maitintojai. Retesnis, tačiau taip pat įmanomas erkinio encefalito užsikrètimo būdas yra nepasterizuotas karvių ir ožkų pienas, todèl ypač svarbu ir toliau šviesti visuomenę apie saugų pieno vartojimą bei vakcinaciją [13].

\section{Išvados}

1. Nustatytas tiesioginis didejančio erkinio encefalitu sergamumo Vilniaus rajone ir kintančių ligos formų ryšys.

2. Didejant erkinio encefalito sergamumui Vilniaus rajone daugejja meningoencefalitinių, mažèja meningitinių ir encefalitinių ligos formų, dažnesni liekamieji reiškiniai, didejja mirštamumas.

\section{Literatūra}

1. Kunz C, Heinz FX. Tick- born encephalitis. Vaccine. 2003 Apr; 21(1): S1/1-2.

2. ECDC. Tick species - Distribution maps. http://ecdc.europa.eu/ en/healthtopics/vectors/vector-maps/Pages/VBORNET-mapstick-species.aspx

3. Karelis G, Bormane A, Logina I, Lucenko I, Suna N, Krumina A. et al. Tick-borne encephalitis in Latvia 1973-2009: epidemiology, clinical features and sequelae. European Journal of Neurology 2012; 19: 62-68.

https://doi.org/10.1111/j.1468-1331.2011.03434.x

4. Haglund Mats, Gunther G. Tick-borne encephalitis - pathogenesis, clinical course and long- term follow-up. Vaccine 2003; 21: S1/11-S1/18.

5. Ašoklienė L., Mickienė A., Jasulaitienė V., Žygutienė M., Laiškonis A., Morkūnas B. Erkinio encefalito etiologija, epidemiologija, klinika, diagnostika, gydymas ir profilaktika (metodinès rekomendacijos). Vilnius, 2005.

6. European Centre for Disease Prevention and Control. Annual epidemiological report 2014 -emerging and vector-borne diseases. Stockholm: ECDC; 2014.

7. Suss J. Tick-borne encephalitis 2010: epidemiology, risk areas, and virus strains in Europe and Asia - an overview. Ticks and tick-borne diseases 2011; 2: 2-15.

https://doi.org/10.1016/j.ttbdis.2010.10.007

8. Czupryna P, Moniuszko A, Pancewicz SA, Grygorczuk S, Kondrusik M, Zajkowska J. Tick-borne encephalitis in Poland in the years 1993-2008 - epidemiology and clinical presentation. A retrospective study of 687 patients. European Journal of Neurology 2011; 18: 673-679.

https://doi.org/10.1111/j.1468-1331.2010.03278.x

9. Amato-Gauci AJ, Zeller H. Tick-borne encephalitis joins the 
diseases under surveillance in the European Union. Euro Surveill 2012; 17(42):pii=20299.

10. European Centre for Disease Prevention and Control. Annual Epidemiological Report 2016 - Tick-borne encephalitis. [Internet]. Stockholm: ECDC, 2016 [cited 17 February 2017]. Available from: http://ecdc.europa.eu/en/healthtopics/tbe/ Pages/Annual-epidemiological-report-2016.aspx).

11. Dorko E, Rimarova K, Kizek P, Stebnicky M, Zakutna L. Increasing incidence of tick-borne encephalitis and its importance in the Slovak Republic. Cent Eur J Public Health 2014; 22(4): $277-281$.

https://doi.org/10.21101/cejph.a3939

12. World Health Organization (WHO). Vaccines against tick-borne encephalitis: WHO position paper. Weekly Epidemiological Record 2011; 86:241-56; PMID:21661276.

13. Hudopisk N, Korva M, Janet E, Simetinger M, Grgic-Vitek M, Gubensek J. Tick-borne encephalitis associated with consumption of raw goat's milk, Slovenia, 2012. Emerging Infectious Diseases 2013; 19(5): 806-808.

https://doi.org/10.3201/eid1905.121442

\section{THE EFFECT OF CHANGING TICK - BORNE ENCEPHALITIS MORBIDITY ON CLINICAL FORMS G.Kalvelytė, A.Žibūdaitė, D.Radzišauskienẻ}

Key words: epidemiology, meningoencephalomyelitis, tickborne encephalitis, vaccination.

Summary

The aim is to evaluate epidemiology and clinical manifestations of tick-borne encephalitis (TBE) in 2011-2014 and 2005-2008.

Working object. A retrospective study was conducted: tickborne encephalitis in the Vilnius district in 2011 - 2014, with a high incidence (13.1 cases per 100,000 population) and 2005-2008 when the incidence was low (3.7 cases per 100,000 population). Adult patients with tick-borne encephalitis who were treated at the Infectious Diseases and Neurology Centers of Vilnius University Santara Clinics in 2005-2014 were investigated.
Method. Only laboratory confirmed cases were included in the study: with tick-borne encephalitis virus IgM and IgG in the blood or with tick-borne encephalitis virus IgM in the liqueur. Patients were divided into two groups according to morbidity level for the period of 2011-2014 $(n=417)$ and 2005-2008 $(n=130)$. The groups were compared according to epidemiology, clinic and residual phenomena. Statistical analysis was performed using $\mathrm{R}$ statistical package, chi-square, Fisher tests; $\alpha=0.05$.

Results. In 2011-2014, when the incidence in Vilnius district increased, compared to 2005-2008, it was found that the number of meningitis diseases decreased - 33/417 (7.91\%) compared to $19 / 130(14.62 \%),(p=0.023)$, also decreased encephalitis forms $12 / 417(2.88 \%)$ compared to $9 / 130(6.92 \%),(p=0.023)$. Meningoencephalomyelitis forms increased by $18 / 417$ (4.32\%) compared to $1 / 130(1.32 \%),(p=0.054)$. Frequency of symptoms of meningitis decreased by $255 / 417$ (61\%) compared to $100 / 130$ (76.92\%), ( $p=$ $0.001)$. The incidence of the following symptoms / syndromes increased: ataxia 146/416 (35.1\%) compared to $32 / 130$ (24.63\%), (p $=0.026)$, tremor $229 / 417(54.78 \%)$ compared to $49 / 130(37.69 \%)$ $(\mathrm{p}=0.001)$, cervical nerve damage 188/417 (44.98\%) compared to $44 / 130(33.85 \%)(\mathrm{p}=0.025)$ and headache $385 / 416(92.55 \%)$ compared to $112 / 130(86.15 \%)(p=0.026)$. Residual phenomena have increased: head dizziness $(\mathrm{p}=0.028)$, ataxia $(\mathrm{p}<0.05)$ and tremor $(\mathrm{p}<0.01)$. In 2011-2014 there were 4 deaths $(0.96 \%)$ compared to 2005-2008 when there was no death $(\mathrm{p}=0.264)$.

Conclusions. There is a direct link between the incidence of tick-borne encephalitis in the Vilnius area and the changing forms of the disease. When the incidence of tick-borne encephalitis in the Vilnius area increases, the number of meningoencephalitis diseases also increases, but the forms of meningitis and encephalitis are decreasing, more frequent residual phenomena and mortality.

Correspondence to: gabrielek13@yahoo.com

Gauta 2019-02-17 